\title{
Navigating Design History with a More Culturally Calibrated Compass
}

Nan O'Sullivan

Keywords: \#Indigenous knowledge \#Design pedagogy \#Froebe \#Bauhaus \#Transition design

It seems remiss that while New Zealand's design prowess continues to impress globally, the indigenous and cultural knowledge that has for centuries inspired and informed aesthetic languages worldwide has not been recognised for its contribution. Forgotten, or perhaps conveniently ignored, is the praise of both the New Zealand Māori and Pacific people's use of nature's harmonies to achieve beauty in aesthetics made in 1852 by education and aesthetic reformist, Owen Jones (1809-1874) in his seminal and determinative work, The Grammar of Ornament. In order to reinstate Jones' claim, this paper asserts it is critical that we revisit design's history from a less Eurocentric perspective. This offers an opportunity to debunk the counter-claim that indigeneity was counter-productive to the development of modernity. By recalibrating design's history with a more accurate and culturally orientated compass, the contributions made by indigenous knowledge to the endeavours of some of design history's most iconic contributors becomes tangible. Having made these connections, this study will introduce Māori and Pasifika ideologies of time, space and connectivity to demonstrate a pathway forward in which this knowledge can be understood, acknowledged, respected and most importantly appropriately included within design's histories, current practices and future endeavours. 


\section{CONNECTING THE EAST WITH THE WEST}

Although diversities are acknowledged as being highly valuable to design, when explored as non- western cultural and creative practices, quixotically they are found to be still side-lined within design curriculums that are dominated by Eurocentric, hegemonic and linear ideals. This paper asserts that to navigate thinking and praxis through this partisanship, a more culturally calibrated compass would serve design well. Required to enable this is an appreciation that indigenous knowledge is not old knowledge or knowledge only relevant to distant, now outmoded times. Although an ever increasing number of tertiary graduate attributes note the merits of cultural diversity and acknowledge the value of non- western social, cultural, and creative practice, curriculums continue to be dominated by Eurocentric paradigms. Proclaiming an inclusive approach to be beneficial to both the institute and the profession, words like synergy, relationships and connectivity are used as the newly defined tenets of an improved or perhaps refocused tertiary design education. These proclamations sound convincing, yet there is still much to be done to position indigenous knowledge within design education, thinking and praxis.

This paper suggests one of the first steps forward is to recognise the contributions traditional knowledge has made as part of the discipline's history and disseminate it more accurately within the curriculum. Eurocentric ideals dominated design education in New Zealand from its establishment as a discipline in the mid twentieth century. This is well after the colonial period and positions design education as quite distinct from traditional art and craft. As a result design education has regarded indigenous knowledge as having little to offer the discipline and continues to be dominated by a working model that privileges western influences. In recent years an increased demand for diversity within design education and practice has gone some way towards re-evaluating the Eurocentric occupation of this discipline. Design theorist Alain Findeli argues that twenty first century design needs to further "open up the scope of inquiry" and calls for more collective and culturally inclusive design practice to achieve it. ${ }^{2}$ Fern Lerner further defends this shift and suggests a more inclusive approach would ensure the aesthetic language of the future does not become constricted or impeded. ${ }^{3}$ Solidifying this motivation, are Terry Irwin and her fellow provocateurs within the Transition Design movement. Transition Design recognises indigenous wisdom as knowledge that has enabled people to live sustainably in place for generations, informed by the 'slow knowledge' embedded within their cultures. Design, this group affirms, has a lot to learn from the symbiotic relationships embedded in indigenous ideologies. Building on Irwin's words that, "Transition Design draws on knowledge and wisdom from the past to conceive solutions in the present with future generations in mind, ${ }^{\prime 4}$ this paper argues New Zealand design education could lead such a shift. To do so, our design curriculums need to become more culturally accurate and inclusive of indigenous wisdom and to include that knowledge in its pedagogy and histories. By example, this inclusion would ratify the use of indigenous knowledge globally and ignite the inclusion of this much needed wisdom into design education and praxis.

Recently I attended a lecture that Paola Antonelli, Senior Curator, Director of Research and Development at MoMA and renowned author, gave to a group of postgraduate students in New York City. Antonelli, clarified that her presentation was a brief and succinct trajectory through design's definitive moments, and in line with that, the well told historic moments flashed up on the screen; the Industrial Revolution, the Vienna Secession, Russian Constructivism, the Bauhaus, the International Style and of course the grand finale, American Modernism. The personal insights offered numerous segues and insightful diversions leading to America's current contributions to design. Although not asked of Antonelli, when the question of cultural influences on design's history is posed, the answers for the most part, are limited to references of either its removal or if pushed, historians will discuss Japonisme. This phrase was coined by French critic Philippe Burty $(1830-1890)$ a quarter of a century after Jones' reference to the importance of the stylised aesthetics of both the Māori and Pacific cultures. Similarly Burty referenced the effect of flatness, colour and stylisation to champion pure beauty as quintessential components of the newly forming design principles. The universal model of design's history offered predominantly by Sigfried Giedion, Nikolaus Pevsner, Rayner Banham and David Raizman not only perpetuates the current working model noted earlier, but also guides the majority of design's history taught worldwide, purposefully or just ignorantly, towards the notions of indigeneity as counter-intuitive.

In the early twentieth century, Austrian architect and follower of Vienna Secession, Adolf Loos (1870-1933) scorned ornament, labelling it degenerate, and no less than a crime. ${ }^{5}$ It was as part of this admonishment that Loos specifically denied the relevance of indigenous aesthetics to the evolution of modernity. This defamation 
was one of the earlier and most fanatical outbursts. It initiated the turning point in which the study and the expression of ornament as a reflection of culture, religion or narrative were eliminated from the curricula of art and architecture. ${ }^{6}$ Contrary to the histories disseminated, this study argues that references to culture, understood in the nineteenth century as excessive, and meaningful to only those of little sophistication, were not unequivocally removed from aesthetic education. If not yet celebrated within the design's history as having contributed to the pursuit of beauty or the roots of modernist design, indigenous knowledge certainly demonstrated and continues to demonstrate numerous visual strategies and ideologies that suggest their pre-existence and their influence on both the reductive codes of the aesthetic language instigated by the reformists and used in the development of the universal visual language by design modernists. In addition, Māori and Pasifika understandings of time and space are also articulated, although not acknowledged in the manifestos and practices of a number of modernists. It is these strategies and ideologies that this research seeks to clarify within design histories taught. To address this claim, an abridged version of this history is offered as context.

\section{AN ABRIDGED HISTORY}

As an article of culture, ornament is as important as it is misunderstood. Whether regarded as essential, expressive, wasteful, appropriated or applied, ornament has always been considered as an expression of meaning or function. It speaks to us, and also about us through figurative and rhythmic languages. ${ }^{7}$ Aesthetic education has celebrated formal embellishments from Vitruvius (c. 90-c. 20 BCE) in the first century AD, through Leon Battista Alberti (1404-1472) in the fifteenth century and on into the mid-nineteenth century where it flourished to excess. In this period, ornament, or more accurately, excessive embellishment was considered to be contributing to both wasteful production and ill-conceived design works. As a result the reputation of ornament suffered substantial criticism during the socia reformations led by John Ruskin (1819-1900), Owen Jones (1809-1874) and their associates. While Jones and Ruskin sought to enable a broader and more inclusive appreciation, use and understanding of ornament and sustainable material production through the establishment of design principles, public education and free museums exhibitions, many less enlightened early twentieth century architects and designers began to question the use of ornament altogether. Loos, was the most vehement in leading the charge by defaming cultural expressiveness.

During his work on the Great Exhibition of 1856 Jones developed a close working relationship with the like-minded Henry Cole (1808-1882). Cole would, as an extension of his collaborations with Jones go on to become the first director of the South Kensington Museum, now the renowned V\&A. This relationship enabled Jones to present his theories on ornament to fledgling designers. Through his own work and lectures, Jones had been formulating what he considered to be the key principles for decorative arts. These principles provided the new reforms that framed the beginnings of design education. As a result, in 1856 Jones published his seminal work, The Grammar of Ornament. It is in this work that Jones gathered together what he considered to be the best examples of ornament both historically and geographically in an attempt to encourage designers to interpret and include the underlying principles contained within this exemplary work and attempt to learn from it. At the outset of this work, Jones acknowledged the importance of ornament to all cultures, stating, "There is scarcely a people, in however early a stage of civilisation with who the desire for ornament is not a strong instinct. ${ }^{18}$ Jones immediately turns his attentions to the works of the Pacific, where he gushes, "nothing, therefore, can be more primitive and yet the arrangement shows the most definition and skill." ${ }^{\prime 9}$ Jones goes on to celebrate the instinctive eye, the skill, the beauty and the fitness for purpose expressed in both form and the graphic markings that were carved into, woven around or applied to both Māori and Pasifika forms. "The beautiful New Zealand paddle would rival works of any civilisation. The swelling form of the handle where additional weight is required is most beautifully contrived. True art consists of idealising, and not copying the forms of nature, ${ }^{\prime 10}$ announces the skills, being, wisdom and aesthetic expression of Māori and Pasifika which set these peoples apart from all others. Jones' contribution was hugely influential to the establishment of the reductive graphic code that sits at the heart of modernism. ." The difference between Jones' approach and Loos' was the former's willingness to acknowledge the value, skill and sophistication of indigenous knowledge and the impact it offered modern aesthetic education. Jones, as a forefather to modernism, was one of the first to ratify culture within design when he stated, Māori and Pacific peoples were, "accustomed only to look upon Nature's harmonies, would readily 
enter into the perception of the true balance both of form and colour; in point of fact we find that it so, that in the savage ornament, the true balance of both is always maintained." 12

Jones' enamour with the development of a reductive graphic code did not stop with him. Following on from Jones, French reformist Eugene Grasset (1845-1917) also asserted similar beliefs. Grasset stated, "The return to the primitive sources of simple geometry is a certain guarantee of the soundness of our method." 13 But there had been significant inroads to this before either man's efforts. Their aesthetic and holistic endeavours were preceded by the efforts of European educationalist Friedrich Froebel (1782-1852). Froebel discussed the practice of learning by doing through holistic, practical and creative education, known and still practiced as kindergarten. It is well established that Froebel's precedents enabled and equipped the preliminary development of modernity. ${ }^{14}$ Preceding Froebel were indigenous ideologies and visual spatial strategies and as a keen observer of nature and humanity, Froebel's beliefs were akin to many of these indigenous practices. Both approached the transfer of knowledge from a biological and a spiritual perspective. Froebel's philosophy, like that of the Māori and Pacific cultures, embraced all things in nature as connected..$^{15}$ Froebel's work expressed interrelationships between the living and the innate, again replicating Māori and Pasifika ideologies. I suggest that the affinity Froebel's tenets demonstrate to indigenous knowledge is palpable. The development of a reductive graphic that mimicked indigenous markings and the belief in holism shared between Māori and Pacific ideologies and Froebel's pedagogy advance this assertion.

\section{THE VISUAL CORRELATIONS}

As promised this study will reveal a concealed connection yet to be told as a part of design history; between Froebel's theory, Ruskin and Jones' manifestos, the Bauhaus, and rather unexpectedly, Pasifika visual-spatial languages. Importantly Froebel's work, like indigenous knowledge, honoured the relationships held in the space between nature, things and people. It was upon holistic, sensory, spatial and social ideals that Froebel built his pedagogy and introduced, perhaps more correctly, reintroduced the values of nurturing and respecting the individual and acknowledging their contributions within a larger collective. Froebel's approach, although instigated as early childhood education, has been widely credited with having had a direct "influence in the history of architecture and all plastic arts beyond any predictable proportion." 16 Having impacted Ruskin and Jones' efforts the trajectory of Froebel's teachings remained intact. It is well established, though not told as a part of design history's narrative, that Froebel's teachings also influenced the creative process and social ideologies of Walter Gropius (1883-1969), his Bauhaus masters Johannes Itten (1888-1967), Paul Klee (1879-1940), Wassily Kandinsky (1866-1944), Lázsló MoholyNagy (1888-1967), Swiss architect Charles-Édouard Jeanneret, known to all as Le Corbusier, (1833-1965) and prominent American architects and designers Frank Lloyd Wright (1867-1959), Buckminster Fuller (18951983) and Charles Eames (1907-1978), to name just the grandfathers of western modernism. Froebel's 'Gifts', as his teaching tools are known, introduced a reductive graphic code based on a sparse grammar of straight lines, diagonals and curves to express the abstracted essence of form and space. The Gifts encouraged physical experimentation with scale, balance, unity, perception, connection and divisibility. Froebel's Gifts shifted successively from simple to complex and from two-dimensional to three dimensional, moving through point, line and plane to create interconnected relationships with nature. ${ }^{17}$ It is of critical importance to note, that similar simple grammars and codified instructions for use can also be found in the dentate stamping on the pottery produced by the Lapita peoples dating as far back as $1500 \mathrm{BC}$. The Lapita peoples are the common ancestor of the Polynesians, Micronesians, and Austronesian-speaking Melanesians who colonised the islands of the Pacific, including New Zealand. ${ }^{18}$ These markings are also represented in the patterns, symbols and visual manipulations of the Māori and Pacific cultures, and again in the much later work of Bauhaüsler Gunta Stölzl's weaving in 1928.

Further building on Froebel's teachings were the holistic and abstractive theories cultivated by Itten and Moholy-Nagy within the German design academy, the Bauhaus (1919-1933). The efforts made by Froebel and Bauhaüsler in fashioning the bedrock of a modernist aesthetic education have been acknowledged by numerous established historians. As part of this momentum and the reformist principles of design, Jones had extensively applauded, documented and used indigenous knowledge. The abstracted graphics, flat patterning and ornamentation of Māori and Pacific cultures contributed significantly to his reforms. These aesthetic strategies subsequently became embedded, albeit without reference to Jones' accolades or recognition 


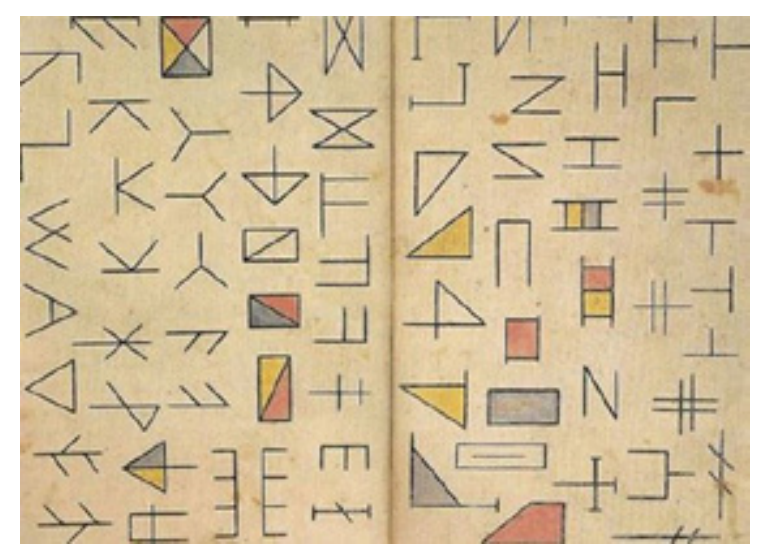

Figure 1. (From left to right) Examples of Lapita markings, 3200-2700 AD. Patrick Vinton Kirch. 'The Lapita Peoples: Ancestors of the Oceanic World, Wiley Global. (This paralleled froebel's wik). See also Norman show codfied graphics that dopict spoth showmars of straight lines, dic sparse curves to express the abstractednaratives.

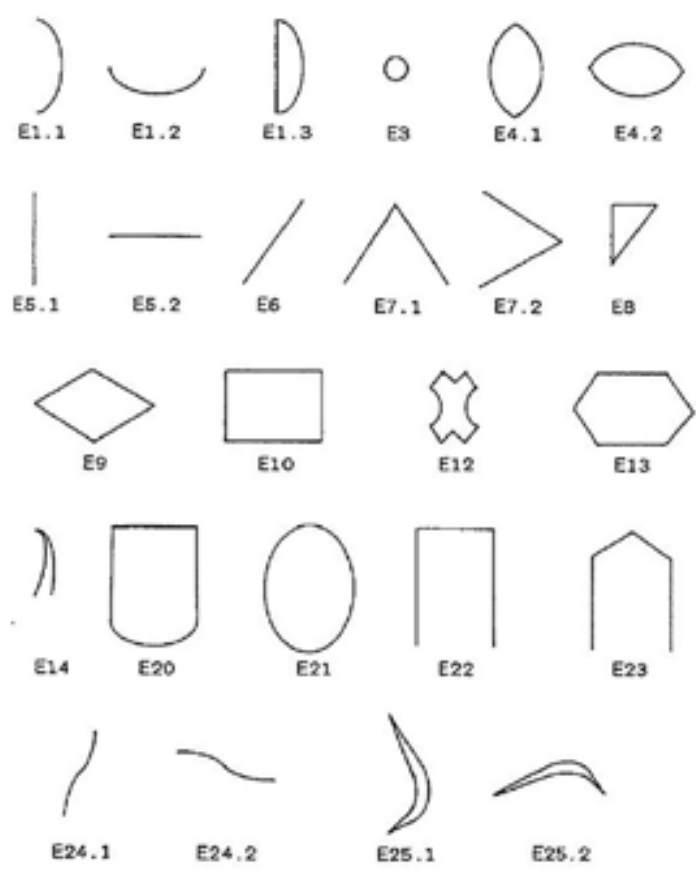

of the cultural influences, in modernist teachings. The new truncated version, devoid of indigenous recognitions continues to be widely disseminated within western design pedagogies and practices today.

\section{CONNECTIONS AND INTERSECTIONS}

Moving beyond aesthetic borrowings, the next comparison made discusses ideology, and posits further historic connections between design and indigenous knowledge that design history fails to incorporate. The ideals of $T a-V \bar{a}$ and teu le $v \bar{a}$, championed by Tongan academic Hūfanga 'Okusitino Mahina in his Theory of Reality enable further ways to connect indigenous wisdom via history, but also project it forward in the annals of design. Ta-Vā is rooted in a holistic view of the Pacific as one, Moana. Although Tongan, the ideology is reflected in other Pacific cultures. The Samoan belief of teu le vā; the eternal nurturing of space relations and vā tapuia; sacred connections, all add a depth and breadth to the ideology.

Samoan academic and poet Albert Wendt's clarification of vā goes some way to articulate an understanding of the space created when connections, interactions and relationships occur and where $T \bar{a}-$ Vā plays out. Wendt wrote, "The space between, the in-betweenness, not empty space, not space that separates but, space that relates, that $v \bar{a}$ holds separate entities and things together in the unity-in-all, the space that is context, giving meaning to things. ${ }^{\prime 19}$ Important to the notions of shared understandings is the common appreciation of the space and relationships that humans, nature and things hold within $T a-$ Vā. Within Māori world views, kaupapa Māori, the relationship between subject and object and culture and nature, also contrasts the western concept of space as separation. "In the Māori world, people and things have close relations that collapse spatial and temporal boundaries." 20

Beyond aesthetic qualities, Froebel also reasoned the existence of, and need to nurture, connections within space. By employing spinning to show how form is perceived to change when treated differently within space, Froebel described appearance and illustrated perception. Froebel historian, Norman Brosterman described this exercise as, "a straightforward demonstration of cosmic mutuality and universal interconnectedness. ${ }^{21}$ Contrasting the Western understanding that separation constitutes space, Mahina places an emphasis on tangible and intangible connections. 
Froebel's exercises similarly expressed immaterial connections, sensory perception and shared understanding; all intangible yet present. Importantly embedded in Ta Vā is the connection to history and legacy and the value to learning held within it. Mahina proffers that, "People are thought to walk forward into the past and walk backward into the future, both taking place in the present, where the past and the future are constantly mediated in the ever-transforming present." 22 Mirroring these sentiments Māori cultural ideology states Hoki whakamuri kia anga whakamua, look to the past to forge the future. Teu le vā speaks to the tethers within these pathways like $v \bar{a}$ that connect entities. These tethers, both tangible and intangible are intergenerational and eternal. Of most importance these connections promote and engender sustainability by instilling an understanding of constant nurturing

Influenced by and developing on from Froebel's educational reforms and motivated by twentieth century industrialization, Bauhaüsler Itten and Moholy-Nagy, as two of the most influential masters, shaped a preliminary year (Vorkurs) pedagogy. ${ }^{23}$ Much of their teaching continues to be central within the modernist educational approaches that still inform aesthetic programmes worldwide. Important to this research is the recognition of the shared ideals between Ta-Vā and those that were embedded in Itten's Vorkurs methodology, understood to be the backbone of Bauhaus pedagogy. These tenets laid a pathway for the exploration and analysis of one's self, nature and the larger world. ${ }^{24}$ This was not done to produce universal or popular stylizing, as wrongly interpreted within midtwentieth century American design history. Ruskin and Jones had initially intended it as a shared and holistic approach to visual, physical and ontological understanding. Itten's tenets, like Ta-Vā and teu le $v \bar{a}$ offered students the ability to see, synthesize emotion and senses, and express the essence of form and space. Itten explained space as: "Walls with windows and doors form the house, but the emptiness in them establishes the essence of the house. Fundamentally, the material conceals utility; the immaterial establishes essence. The essence of a material is its effect on space, the immaterial. Space is the material of the immaterial. ${ }^{25}$ Continuing these teachings Moholy-Nagy stated,

"Today spatial design is an interweaving of shapes; shapes which are ordered into certain well defined, if invisible, space relations; shapes which represent the fluctuating play of tension and force." ${ }^{26}$
When the relevance of Moholy-Nagy's ethical, environmental and socially responsible doctrines were brought into question by his new employers in America in the late 1930s, Moholy-Nagy retorted of these relationships, "The artist's work is not measured by the moral and intellectual influence which it exerts in a lifetime but in a lifetime of generations." ${ }^{27}$ This statement correlates to the indigenous appreciation of inter-generational legacy offered by $T a-V \bar{a}$ and now Transition Design where Irwin and her colleagues consider the importance of establishing a connection between past and present in order to vision the future.

This paper argues that the importance of thinking in and designing for long horizons of time, as indigenous cultures have, and the application of indigenous, local, place-based knowledge as an example of healthy, long-lived societies, infrastructures, beliefs and relationships to enable modern society to become sustainable, cannot be overstated. ${ }^{28}$

By paralleling the historic tenets of both Froebel and the Bauhaus in their endeavours to use reductive graphic codes and holistic principles alongside Mahina's theory, connections are exposed. Importantly, the congruence between the ideals imbued in $T a-V \bar{a}$, teu le $v \bar{a}$ and contemporary design education also becomes evident. This acknowledgement points to the inclusion of indigenous knowledge as far more than an interesting historic or cultural deviation. This knowledge holds significant relevance to a design education that seeks to move beyond a 'solution or artefact based' manifesto to one of interconnectivity between human things and nature that is both sustainable and enriching. Peder Anker states that, "Moholy-Nagy believed the future held the possibility of a new harmony between humans and their earthly environment if forms of design followed biological functions." ${ }^{29}$ Although never before compared, I would suggest a correlation

between the ambitions of Moholy-Nagy and Mahina. Findeli observed of Moholy-Nagy that "the key to our age is to be able to see everything in relationship." 30 The loss of the holistic applications to his teaching was possibly the most significant defeat Moholy-Nagy faced as part of his mid-twentieth century efforts in America. The capitalist and resource rich America had no need of the humanist approach or environmental concerns Moholy-Nagy saw as impacting future generations. Sitting very comfortably alongside Moholy-Nagy's 1947 work, Vision in Motion, is Mahina's argument that current global issues are exacerbated, if not caused by a loss of, "mutually holistic, symbiotic human-environment relationships." ${ }^{31}$

Also never told as part of New Zealand's design history is the 1965 visit by Richard Buckminster Fuller (1895-1983), one of the 
most renowned and formative design scientists to shape the design profession. After Moholy-Nagy, but before such notions were standard environmental thinking, Fuller argued that "the resources offered by the universe; energy, materials and space, were finite and that they had to be seen in terms of their relationships to each other." 32 The little known anecdote, reported by American art critic, Calvin Tomkins is that Fuller visited a rather allusive cultural anthropologist in New Zealand. The word allusive is used because the research being undertaken in New Zealand at the time by Bruce Briggs and Peter Platt of Auckland University to create a Māori Music Archive has yet to agree on who it may have been. But there remains no doubt the anthropologist was, to use Fuller's words, a "Keeper of the Chants of the Māori people."33 Recognising the value of these chants to more than just New Zealand's anthropology but all of humanity, Fuller, encouraged his colleague to record these sacred stanzas. In these discussions, Fuller launched into extensive monologues, recalling seemingly irrefutable data on tides, prevailing winds, boat design, mathematics, linguistics, archeology, architecture, and religion. The apparent take away from his discussion was that Māori had been among the first peoples to discover and understand the principles of celestial navigation. Fuller highly commended Māori for their ingenuity and for being among the first to, "find a way of sailing around the world, a long, long time before any such voyages were commonly believed to have been made." ${ }^{134}$ Initially published in 1969, just four years after his visit to New Zealand, one of Fuller's most popular works, Operating Manual for Spaceship Earth was published. It is a synthesis of Fuller's world view. In it, Fuller investigates the challenges facing humanity. Fuller asks (and answers) how we can utilise our resources more effectively to realise our potential. He calls for a "design revolution and offers advice on how to guide 'spaceship earth' toward a sustainable future." ${ }^{\prime 35}$ This paper asserts that Fuller's declarations around sustainable futures, that included the adoption of future technology, intersects significantly with indigenous knowledge. The suggestion that historic inter-generational, local and place-based technologies and tools can both lead and enhance global knowledge is evidenced when Fuller applauds the Māori navigators for their advanced capabilities. As a Froebel alumni and a kindred spirit to Moholy-Nagy, and I would hope Mahina, had they ever met, Fuller asserted "Space is irrelevant. There is no space there are only relationships."36 Having been lucky enough to meet, present my research to, and at Mahina's invitation now call myself a fellow Ta-vā-ist, I note in a recent group invitation to the international release of his next work Mahina wrote,
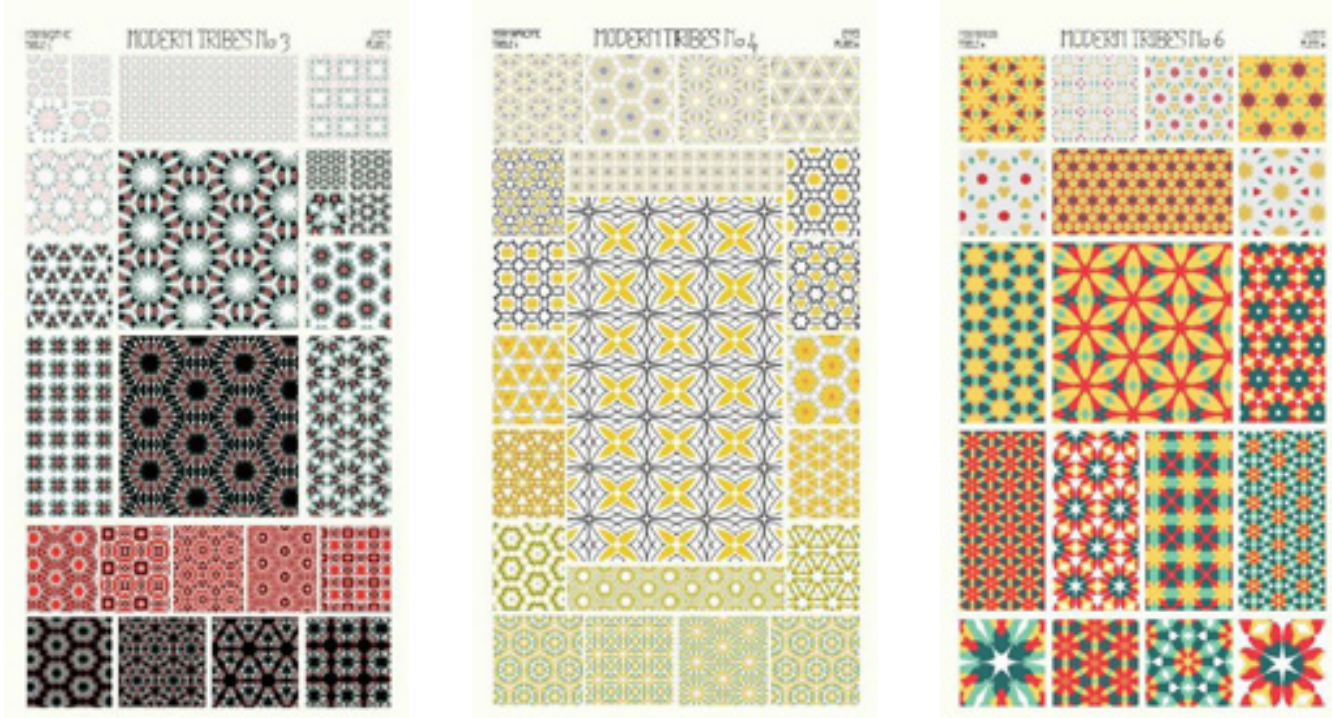

Fig 3. 3 of 6 plates from Modern Tribes; a first year design project where having identified their own cultural affiliations, students make patterns from the individual cultural symbols they designed and seek to express thes as collective and complex group identities. Using the historic format introduced by Owen Jones in the Grammar of Ornament these are grouped as modern tribes within Moana. From left to right, Plate 3. Modern Tribes Moana/ Gothic. Plate 4. Modern Tribes Moana/Maori. Plate 6. Modern Tribes Moana/Asia. 
“Kiaora, Talofa, Fakalofa, Alofa, Aloha \& Si'oto'ofa All Good Folks, Friends \& Colleagues: I hope everything is fine with you all at your end of the so-called Global Village, Spaceship, Earth!" If Fuller is not here to make the connection between their ideologies, I am happy to see that Mahina, the man behind, in front of and a part of Ta-Vā, agrees there is one.

\section{THE REALITY}

In order to incorporate and enable the recalibration of design's cultura compass the value of indigenous knowledge within creative process needs to be recognized. A deeper, more personal understanding of indigenous culture within the design work produced by and with New Zealand, Māori or Pasifika peoples is paramount as a part of this shift. With a focus on the cultural agency that this study argues needs to be included in our design histories, I reference Wendt. He speaks for all inhabiting Moana, not just Oceania, when he resonates; "I belong to Oceania- or at least I am rooted in a fertile portion of it. So vast, so fabulously varied a scatter of islands, nations, cultures, mythologies and myths, so dazzling a creature, Oceania deserves more than an attempt at mundane fact; only the imagination in free flight can hope, if not to contain her, to grasp some of her shape, plumage and pain. ${ }^{137}$ Acknowledging indigenous knowledge as part of our design histories enables both current and future generations of designers to benefit from the holistic indigenous ideologies, narratives and sophisticated visual aesthetics. This also encourages discussions of how respect, reciprocity, mutuality, symmetry and balanced socio-spatial relationships could be engendered into design thinking and practice.

This would, I suggest both adjust the dial on the cultural compass that should be guiding our historic narratives and set us on a path towards the diverse and sustainable futures not only sought but now paramount to humanity. Although poised for change, design pedagogy is well overdue to open itself up to the wisdom embedded in diversity and difference but that unfortunately still remains unheeded in twenty-first century mainstream design curriculums.

This research asserts that by relinquishing the heroic,

teleological and Eurocentric models currently followed within design education a more culturally calibrated compass can be discovered.

\section{REFERENCES}

Anker, Peder. "Graphic Language: Herbert Bayer's Environmental Design." Environmental History 12 no. 2 (2007): 254 - 79.

Badura-Triska, Eva, ed. Diary No. 7, 27 May 1918 Löcker Verlag, 1990 ed. Vol. 2, Johannes Itten. Weisbaden: Löcker Verlag, (1990).

Bayer, Herbert, Walter Gropius, and Ise Gropius, eds. Bauhaus 1919 - 1928. New York: The Museum of Modern Art, 1938.

Bloomer, Kent. The Nature of Ornament. Rhythm and Metamorphosis in Architecture. New York: W.W. Norton \& Company, Inc, 2000.

Brosterman, Norman. Inventing Kindergarten. New York: Harry.N. Abrams, Inc, 1997.

Findeli, Alain. "Rethinking Design Education for the 21st Century: Theoretical, Methodological and Ethical Discussion." Design Issues 17, no. (2001).

Findeli, Alain, and Charlotte Benton. "Design Education and Industry: The Laborious Beginnings of the Institute of Design in Chicago in 1944."

Fuller, R Buckminster. Utopia or Oblivion: The Prospects for Humanity edited by Jamie Snyder Oslo: Lars Muller Publishers, 196

Goldberger, Paul. "Missionaries of Human Possibility Who Sought Solutions for All." The New York Times 1995.

Grasset, Eugene. Methode De Composition Ornementale Par Eugene Grasset Paris: Librairie Central des Beaux Arts 1905.

Henare, Amiria. Museums, Anthropology and Imperial Exchange. Cambridge University Press 2005. Jones, Owen. The Grammar of Ornament. Berkshire, England: Van Nostrand Reinhold Company Limited, 1856.
Kirch, Patrick Vinton. The Lapita Peoples: Ancestors of the Oceanic World Cambridge, Mass: Blackwell Publishers., 1997.

Lerner, Fern. "Liberating Foundations of Art and Design ". International Journal of Art and Design Education 31, no. 2 (2012): 140-52.

Loos, Adolf. Ornament and Crime. Riverside California Ariadne Press 1908.

Mahina, Hau'ofa Okusitino. "Our Sea of Islands." The Contemporary Pacific 6, no. 1 (1994): 148-61.

-. "Tā, Vā and Moana: Temporality, Spatiality, and Indigeneity." Pacific Studies 33, no. 2/3 (2010). McFall, C. B. N. M. M. J.-J. Y. B. S. “Design Thinking: Promoting Diversity through Global Immersion."

Family and Consumer Sciences Research Journal 37, no. 3 (2009): 344-58.

Terry Irwin, Gideon Kossoff, Cameron Tonkinwise, Peter Scupelli. "Transition Design" Carnegie Mellon University

Tomkins, Calvin. "In the Outlaw Area." The New Yorker January 81966.

Wendt, Albert. "Tatauing the Post-Colonial Body." SPAN: Journal of the South Pacific Association for Commonwealth Literature and Language Studies 42, no. 43 (1999).

-- - ed. Towards Oceania. Edited by Guy Amirthanayagam, Writers in East-West Encounter: New Cultural Bearings, Auckland Macmillan Press Ltd, 1982.

Wick, Rainer K. Teaching at the Bauhaus. Translated by Stephen Mason and Simon Lèbe. Ostfildern-Ruit: Hatje Cantz Verlag, 2000

Wingler, Hans. The Bauhuas. Weimar, Dessau, Berlin, Chicago. Cambridge: MIT Press, 1980. 


\section{ENDNOTES}

1 C. B. N. M. M. J.-J. Y. B. S. McFall, “Design Thinking: Promoting Diversity through Globo Immersion" Family and Consumer Sciences Research Journal 37, no. 3 (2009).

2 Alain Findeli, "Rethinking Design Education for the 21st Century: Theoretical, Methodological, and Ethical Discussion," Design Issues 17, no. 1 (2001)

3 Fern Lerner, "Liberating Foundations of Art and Design" International Journal of Art and Design Education 31, no. 2 (2012).

4 Gideon Kossoff, Terry Irwin, Cameron Tonkinwise, Peter Scupelli, "Transition design" Carnegie Mellon University

5 Adolf Loos, Ornament and Crime (Riverside California Ariadne Press 1908).

6 Kent Bloomer, The Nature of Ornament. Rhythm and Metamorphosis in Architecture (New York: W.W. Norton \& Company. Inc, 2000). 1

7 Ibid, 9.

8 Owen Jones, The Grammar of Ornament Berkshire, England: Van Nostrand Reinhold Company Limited, 1856). 1

9 Ibid, 2.

10 Ibid. 3

11 Rainer K Wick, Teaching at the Bauhaus, trans. Stephen Mason and Simon Lèbe (Ostfildern-Ruit: Hatje Cantz Verlag, 2000). 95.

12 Jones, The Grammar of Ornament: 14.

13 Eugene Grasset, Methode de Composition Ornementale par Eugene Grasset (Paris: Librairie Central des Beaux Arts 1905). 115.

14 Norman Brosterman, Inventing Kindergarten (New York: Harry.N.Abrams, Inc., 1997). 119.

15 Ibid, 45.

$16 \mathrm{lbid}, 119$

17 Ibid, 51.

18 Patrick Vinton Kirch, The Lapita Peoples: Ancestors of the Oceanic World. (Cambridge, Mass: Blackwell Publishers., 1997). 240.

19 Albert Wendt, "Tatauing the Post-Colonia Body," SPAN: Journal of the South Pacific Association for Commonwealth Literature and Language Studies 42, no. 43 (1999): 204.
20 Amiria Henare, Museums, Anthropology and Imperial Exchange (Cambridge: Cambridge University Press 2005). 3.

21 Brosterman, Inventing Kindergarten: 45.

22 Hau'ofa Okusitino Māhina, "Our Sea of Islands.," The Contemporary Pacific 6, no. 1 (1994): 170.

23 Wick, Teaching at the Bauhaus: 93.

24 Hans Wingler, The Bauhuas. Weimar, Dessau, Berlin, Chicago (Cambidge: MIT Press, 1980).

25 Eva Badura-Triska, ed. Diary no. 7, 27 May 1918, Löcker Verlag, 1990 ed., vol. 2, Johannes Itten (Weisbaden: Löcker Verlag 1990).

26 Herbert Bayer, Walter Gropius, and Ise Gropius, eds., Bauhaus 1919 - 1928 (New York The Museum of Modern Art, 1938), 122.

27 Alain Findeli and Charlotte Benton, "Design Education and Industry: The Laborious Beginnings of the Institute of Design in Chicago in 1944," Journal of Design History 4 no. 2 (1991):

28 Terry Irwin, "Transition design".

29 Peder Anker, "Graphic Language: Herbert Bayer's Environmental Design," Environmental History 12, no. 2 (2007): 256.

30 Findeli, "Rethinking Design Education for the 21st Century: Theoretical, Methodological and Ethical Discussion," 10.

31 Hau'ofa Okusitino Māhina, "Tā, Vā and Moana: Temporality, Spatiality, and Indigeneity," Pacific Studies 33, no. 2/3 (2010): 171.

32 Paul Goldberger, "Missionaries of Human Possibility Who Sought Solutions for All," The New York Times 1995, 40

33 Calvin Tomkins, "In the Outlaw Area," The New Yorker January 81965

34 Ibid.

35 lbid.

36 R Buckminster Fuller, Utopia or Oblivion: The Prospects for Humanity ed. Jamie Snyder (Oslo: Lars Muller Publishers, 1969). 31.

37 Albert Wendt, ed. Towards Oceania, Writers in East-West Encounter: New Cultural Bearings (Auckland Macmillian Press Ltd, 1982), 202. 